\title{
What is Microhistory?
}

\section{Jesse Paul}

Virginia Tech

\begin{abstract}
The following paper is a michrohistorical intervention in one aspect of David Graeber's meta-narrative in Debt: the First 5,000 years. Graeber posits four overarching cycles of world history based on the alternation of the systematic use of coinage and virtual credit money. This grand narrative is set explicitly in the context of world-systems analysis and has received surprisingly little attention from scholars. In this intervention, I define what microhistorical practice is, I situate microhistory in the intellectual context of intervening in large grand narratives - either to shed light on them, problematize them, raise new questions about them, or perhaps even in some cases overturn them. Microhistorians do not avoid narrative, but they seek a return to narrative through a close analysis of small events situated within larger frameworks. Finally, I explore preliminary and approximate applications of microhistory to the Axial Age bullion cycle, one cycle in the great alternations between credit and coin. I focus on one specific philosopher - Plato, and create a microhistorical account of his actual relationship with Archytas, a Pythagorean philosopher, who I claim, is the living inspiration for the philosopher king's in Plato's utopian imaginary Kallipolis, the famous ideal city-state of his Republic.
\end{abstract}

Microhistory is a historical practice aimed at a return to narrative through detailed analysis of primary documents. Microhistorians are generally concerned with overlooked persons, and marginalized voices. They wish to gain understanding and insight into the properties of large-scale global processes and events by looking at the finely textured details of everyday life during the chosen time period under study. Ideally, a microhistory will not simply be a biography, nor will it be primarily the analysis of a small village, although a person's life or village can serve as a site of analysis. Instead, microhistorical practice is about developing an observational lens, or a point of view, onto larger landscapes and structures of history.

Social Evolution \& History, Vol. 17 No. 2, September 2018 64-82

(C) 2018 'Uchitel' Publishing House

DOI:10.30884/seh/2018.02.04 
The larger the landscape, the more important it is to have several sets of eyes, arranged at certain potentially illuminating positions, in order to appreciate the full range and complexity of the historical structures we wish to understand. If we extend this metaphor to the field of all written history, then the role of microhistorians would be to find those points of view from which our limited gaze onto the past can survey such a landscape in its richest diversity (see Levi 1991: 93-113). ${ }^{1}$ As the name suggests, a point of view is microscopic and limited. However it may be that it is precisely through those limited, marginalized, and forgotten points of view in history that we stand to gain clear insight into the past.

Unlike the geographical landscape in our metaphor, however, the field of time and the passing of events may not be best understood from above. The metaphor fails us because history is not like the Grand Canyon or Mount Everest, large overarching structures best viewed from photographs taken inside the safety and comfort of planes or helicopters. Conceptual frameworks like longue dureés, or class conflict, are like trying to fly over and above history, and photograph enormous features. But, by looking down from these great heights, we can often overlook the human elements below.

The structures of history are not simply like the structures of geology. Tectonic plates do not appreciate the beauty of the mountains they form, nor can they experience them. It is the human being who interacts with the structures of geology and in the domain of history, humans also create and fashion those structures in a reciprocal relationship. Social, cultural, and material structures are created by and in turn help create the human world: homes, relationships, universities, cities, links of trade, and written words. Sometimes it may do no good flying above these structures in order to view their complicated interactions. At crucial junctures, we may have to look at all the details of the paths surrounding the sojourns below, and once again change our scale of analysis.

Some features we saw from the helicopter no longer matter, while other features we overlooked (perhaps, the wind and the cold) play a role and interact strongly inside the small scale. By moving down from the safe hierarchy of the photographer in the plane to the person who has to make the journey, we gain insight into how the large is felt by the small. Given enough context, we might even be able to recreate the mental life of the participant. If we knew the rocks were razor sharp, the wind was turbulent, and the temperature was below freezing, we can begin to surmise how a climber may have felt. Of course, we would never have direct evidence of how they felt, but through a detailed analysis of the various features and obstacles surrounding the climb, we can make reasonable inferences as to what it might have been like. Perhaps, we can even uncover a narrative, or discover a truth. 
The canonical books of microhistory are precisely those works that uncover narratives and shed light on larger historical structures. Natalie Zemon Davis's Return of Martin Guerre, for example, recreates the lives of the sixteenth-century peasants and sheds new light on the social structures of the time. Crucially, it illustrates how peasant women were able to exploit aspects of this patriarchal world to their favor. This comes to light over the course of telling a story about Arnauld du Tihl, a peasant who is able for quite sometime to pretend to be Martin Guerre, fooling most of the villagers and living in every way as if he were the Real Martin Guerre. Through a detailed analysis of inquisitorial records, Davis is able to recreate this drama and unveil a really existing narrative - a story that really happened - and use this story as a way of asking questions about social history (Davis 1983). In this work, Davis is not so much concerned with overarching structures like world-systems, or revolutionary moments, but is choosing to intervene in a well-known story through a close examination of court records. By showing how Arnauld knew almost impossible details about everyone he met, how he was physically different in size, and how the behavior of Bertrande and Arnauld changed over the course of their invented marriage, and the later court case, Davis is able to show that Bertrande was a collaborator who was choosing to go against certain accepted mores in order to maintain a happy relationship (Davis 1988). ${ }^{2}$

In choosing this particular point of view, Davis intervenes on certain assumptions about women in the sixteenth-century village life.

This was a specific intervention aimed at overturning certain assumptions, but there are broader interventions in microhistory as well. Donald Wright's The World and a Very Small Place in Africa is such a text. By focusing on a small place over a long time period, Wright overturns assumptions about the Atlantic slave trade and sheds new light on how global processes affected the political and social structures in Niumi of The Gambia (Wright 2010).

The chosen technique of analysis here is a reduction of spatial scale, while the temporal scale is from the fifteenth through the twenty-first century. In Davis's case we had a reduction of scale spatially, temporally, and structurally (by focusing on a relationship) whereas in Wright's case the reduction of scale is only spatial, and is not concerned with focusing on an individual. However, in both cases we find a detailed analysis aimed at shedding light on larger structures: in one case social structure, in the other case, a world-system/economic structure. The choice of reduction in analysis is up to the microhistorian, and there are probably as many choices as there are historical events. The aim however is the same: to see the world in a grain of sand. ${ }^{3}$

There are microhistorical works that combine aspects of both social and economic structure as well. Le Roy Ladurie's Montaillou is a thick description of a fourteenth-century village and discusses economics, cul- 
ture, the inquisition, religion, magic, power, marriage, and medieval perceptions regarding the fate of the human soul. After reading Ladurie's work one feels as if this French professor succeeded in creating a literary time machine. In this case we have certain assumptions overturned about the past as well. From the perspective developed in Montaillou, life did not seem all that bad in the dark ages - except for maybe the lice. Of course, the inquisition eventually intervenes savagely, but it seems that for most of the time, some of the great centers of power encircling the village and its environment, like the church and the monarchs, more or less kept from intermingling in the villagers' everyday affairs (Le Roy Ladurie 1978). ${ }^{4}$

There are also canonical works of microhistory that shed light on the intellectual aspects of global structures. Carlo Ginzburg's The Cheese and the Worms, for example, investigates the world-view of a sixteenth-century miller and shows how his philosophy refuses neat categorization into the dominant systems of sixteenth century thought (Ginzburg 1980). This work challenges the intellectual trickle-down theories of philosophical development: as if peasants, workers, or villagers develop their views only to the extent that they can internalize and understand the views of the contemporary literati. Ginzburg shows that there is a rich tradition of peasant culture, replete with honorable and complex ideas, and that these can interact with the dominant systems of power/knowledge of the day from the bottom up.

We can see how the microhistorian is confronted with a number of crucial choices. These decisions involve change of scale, aim of intervention, and collection and analysis of primary sources, and these choices all hinge on what sort of historical intervention the historian wishes to make. Is the aim to find a particularly compelling point of view from which to look at world systems? Is it to overturn assumptions in social history? Maybe the goal is to gain a deeper insight into the development of a sixteenth century Miller's cosmological system during the Reformation? In the end, the unifying thread is detailed analysis of primary sources through the lens of a restricted scale. The work that most inspired me for my project is Carlo Ginzburg's The Cheese and the Worms, which aims to shed light on the complex problems in intellectual histories. ${ }^{5}$

For my purposes, I will look at the interaction of lived everyday life on the formation of dominant ideas. Specifically, I want to look at the history and life of Archytas, a Pythagorean philosopher, whose role in the warringcity states at the time - as well as his philosophy - influenced Plato's ideal city state Kallipolis, as well as the ideal of the Philosopher Kings.

\section{ARCHYTAS THE PHILOSOPHER KING}

With this in mind, I have attempted a microhistorical project of my own. I have chosen to reduce the scale of analysis to one city-state and one 
person in order to ask a question about Plato's Republic, a text considered to be one of the foundational works in Western philosophy. It is concerned with moral and political philosophy, and the arguments contained within it have been debated and discussed for over 2,000 years. One of the central arguments of the Republic is that certain philosophers, who by their natures understand the true form of the Good and can properly create just social arrangements, should rule the ideal city-state as Philosopher-Kings.

I would like to raise questions about the origins of the Philosopher King idea. Were there specific events or persons who inspired Plato's model of Kallipolis and the Philosopher Kings? In order to investigate the influences on Plato's concept of the Philosopher King, I have turned to recently translated fragments of a 'lost Pythagorean'6 named Archytas. I hope to show through a close analysis of the city-state in which he lived, and the writings and ideas that he had, that Archytas was Plato's real life inspiration for the famous 'Philosopher King' concept.

Hence, in this case, our marginalized point of view will be reconstructed through recently translated fragments concerning the work of Archytas. I have chosen to place these fragments in the Appendix, though these are the primary sources I am using in order to shed light on Archytas's influence on Plato and hence in significant ways Western Philosophy. There has not really been any new work on early Pythagoreanism for about 160 years, and so I am heavily indebted to the philological work of Carl Huffman, who put together a detailed commentary and interpretation of the works of Archytas. In fact it is the first detailed study of Archytas's work in any language. In addition, Huffman has also worked through texts of Philaus of Croton, and these two works are beginning to provide a firmer foundation for studies of the early Pythagorean thought.

\section{THE PYTHAGOREAN KALLIPOLIS}

Archytas was a Pythagorean philosopher born between 435 BC and 410 BC. $\mathrm{He}$ is also involved in Plato's infamous Seventh Letter, where it is claimed Archytas sent a trireme to rescue Plato from Dionysus II of Syracuse. ${ }^{7}$

Archytas lived in the city-state called Tarentum, an emerging powerful city-state about the size of fifth-century Athens. Tarentum was originally a colony inside the Spartan military-coinage-slavery complex (see Ingham 2004). The urban planning and architecture of the Spartan citystates were most likely similar to those described by Hippodamus of Miletus (Sturgis and Davis 2013: 386). They would have been close to a grid pattern, with various households located around near the polis, or the temple. Stretching outwards from this center were farmlands, workshops, and on the outskirts of the city-state, industrial sized mining operations, worked by hundreds of slaves (Finley 1985: 21). 
The Spartans would employ their war-captives in the mines, mint new coins, and impose a tax on the newly conquered population. In the ancient world taxes were normally not levied on the citizens of the colonizing state; they were levied on the inhabitants of the conquered city and redistributed back to the mother-colony. This system of wealth distribution could be used for public works such as the famous Roman bread and circuses, or to pay people to vote or attend jury duty. This made it easier for ancient regimes to provision their soldiers as well. Instead of sending food and necessities and extra transport, the soldiers and tax collectors could extract resources directly from the new colony by forcing them to adopt the newly minted coins.

The Tarentum city-state was situated behind the west facing shores of where the Ionian Sea washes into Italy's boot, and Archytas was honored for his harbor-town, its being the 'natural stopping point' for ancient fleets of triremes and pentakonters sailing from the east facing foreslopes, cliffs, and beaches along that western side of the boot, or outward from Tarentum into the Adriatic, 'sending forth ships into all lands' ${ }^{8}$ It is said that peoples known as the Iapygians, the Messapii, and the Daunians, who all lived around the heel of Italy, originally occupied this region around Tarentum. We know very little about these peoples. There are scarce records, presumably because of the extraordinary level of violence in this area circa 450-350 BC. ${ }^{9}$ This is important to note because Plato believed that the kind of violence between constantly warring city-states in the Mediterranean would not cease until rulers became like idealized Philosopher Kings. $^{10}$

In the middle of the fifth century the Spartans successfully colonized the Messapians, but not the Iapygians, who eventually overthrew the violent domination of the new bullion-economy. ${ }^{11}$ They rose up in arms, defeating the Tarentine's and their allies. ${ }^{12}$ Because so many of the nobles died in this battle, democratic elements of the rebellion were able to reshape Tarentum into a democratic city-state, as recounted by Aristotle in Politics (Aristotle 1303a). ${ }^{13}$

Tarentum's constitution became democratic sometime after the Iagpygian colonial rebellion, a few generations before Archytas was born. He would grow up to become elected strategos, or governor, for seven years in row (see Appendix, Fragment 3, A1 and A1f).

When Archytas was strategos, Tarentum was about the size of fifth century Athens. According to Strabo, Tarentum 'possessed the greatest fleet of those in the region and sent to battle 30,000 foot soldiers, 3,000 Calvary, and 1,000 mounted javelin throwers' Appendix, A4). ${ }^{14}$

This is important since in Plato's ideal city state the guardian of the city is 'both a warrior and a philosopher', and the city-state has a welldeveloped and effective military (Republic 525b5). This is suggestive, but 
in order to make the connections tighter, we need to ask about the relationship between Plato and Archytas. We then need to investigate the overlap of the ideal Philosopher king with the real Archytas. It is also useful to investigate the social structures of Tarentum as a democratic city-state, and the habits of Archytas. Then we can compare his lifestyle, outlook, and philosophy with the discussion of the ideal philosopher and city-state in The Republic.

We have little information concerning the actual voting practices of democratic Tarentum, though there is evidence that Archytas believed in the procedure of lot, or dice rolling. We also know that Tarentum was famous for having a 'communal' lifestyle, and no strong gradations between rich and poor (Huffman 2010: 184).

Some of the best evidence concerning Tarentum comes from the writings of Aristotle (Ibid: : 17). Aristotle praises Archytas' policy of making some of the wealthy's possessions available to the poor (Ibid.).

Now that we know the background, and we know that Tarentum would have become democratic before Plato wrote the Republic, it is hard not to immediately think of Tarentum when Socrates says that 'Then democracy comes about, I suppose, when the poor are victorious, kill or expel the others, and give the rest an equal share in the constitution and the ruling offices, and the majority of offices in it are assigned by lot' (Republic 557a5). These are exactly the policies Archytas implemented, and the events are the same as those preceding his election to stategoes seven years in a row.

Though, while Plato's description (in the mouth of Socrates) of the way democracy comes about and the history of Tarentum's political constitution are almost identical, this by no means implies Tarentum and Archytas were Plato's exact models for Kallipolis and the Philosopher Kings. However, it is hard not to think that this 'lost Pythagorean' and his city-state influenced Plato's ideas. It was in some sense a really existing Kallipolis, an island of stability and democracy amidst a sea of war and tyranny. Plato found refuge there a number of times, and the influence this city-state and it is mathematician king had on Plato becomes clearer when we turn to Plato's relationship to Archytas.

\section{ARCHYTAS AND PLATO}

We know a little bit about Archytas's personal life. Archytas owned a very large estate, and enjoyed having many guests (Huffman 2010). He also had 'guest-friends' which in the ancient world meant he was required to provide an array of services, especially room and board during travels (Ibid.). Plato was one of these guest friends. He also probably had a number of guest friends in the Italian League, which he was apart of at the time (Ibid.). 
There are conflicting traditions concerning the relationship between Plato and Archytas, and modern scholarship has called into question the exact nature of the relationship (see Lloyd 1990 for a discussion of the problems concerning their friendship). Some traditions present Archytas as a Pythagorean master with whom Plato studied, while others present him as a philosopher with an imperfect grasp on Plato's system of philosophy, who then only became important in the political world after meeting with Plato. ${ }^{15}$ However, both traditions indicate that Plato traveled around Italy and Sicily after Socrates died in 399 BC, about nineteen years before he would write the Republic. ${ }^{16}$

Since we can be fairly certain that Plato was traveling around Italy after Socrates death, it is possible he was seeking out leading thinkers in the area. Archytas was highly regarded in the ancient world, and perhaps Plato was not seeking him out as a teacher, but as an expert on mathemata. If it is correct that Plato met Archytas around 388/7 BC, right about when Tarentum was rising to power, then first strand would be correct in claiming Archytas was a teacher of sorts for Plato, and the second strand would be correct in pointing out that Archytas did not rise to power until after he met with Plato. ${ }^{17}$

In either case, however, we know that Archytas and Plato had many social interactions, and that they were guest-friends before Plato would write the Republic. We also know that Plato would become interested in mathematics around this time (Huffman 2010: 41). These facts will be important when we turn to consider Archytas' writings and ideas, and specifically where they show up in Book VII of Plato's Republic.

\section{ARCHYTAS' PHILOSOPHY}

Archytas' major works were On Harmonics, and On Things Scientific. He also published works of metaphysics, of which we only have fragments. He argued in On Things Scientific that being able to make precise distinctions is a path to knowledge, and he was primarily concerned with the science of number. It is by making distinctions, Archytas asserts, that we grasp the particulars. The particulars give us insight into the whole. To do this properly requires what he calls logistics, which is a rudimentary number theory.

Archytas holds arithmetic leads toward truth, and also prevents discord and injustice (Huffman 2010: 182). He also has a number of interesting points about our ability to perceive the world, which seems to be based on the limiteds and unlimiteds concept of Philolaus. ${ }^{18}$ Archytas holds that humans will simply not perceive some things, since there are things that are greater in their 'limit' than human perception.

Indeed many of these sounds cannot be recognized because of our nature, some because of the weakness of the blow, others 
because of the distance of separation from us and some because of the excess of the magnitude. For the great sounds do not steal into our hearing, just as nothing is poured into narrow-mouthed vessels, whenever someone pours a lot.

But let these things be enough on this topic. It is clear from these things that this intelligible ordering of melody, in itself, would seem to increase without limit, but, if it is transferred to the voice and the hearing, it does not have an unlimited extension but is limited by our ability (see Appendix, A1).

Notice the example of a large amount of water being poured into a narrow vessel. It is easy to picture how the volume and intensity of the fluid is too great to 'be perceived' and fill up the vessel. Archyta's is concerned with sound here, but the principle applies to astronomy as well in his On Things Scientific. We can make distinctions and calculate magnitudes 'concerning the speed of the stars and their risings and settings' (Huffman 2010) and this will give us knowledge of the phenomenal world. ${ }^{19}$ This makes the two sciences akin. As he puts it, '[...] as well as concerning geometry and numbers and not the least concerning music, they handed down to us a clear set of distinctions. For these sciences seem to be akin' (Appendix, A1).

Consider Plato echoing these exact points, almost verbatim, after the Allegory of the Cave,

But these fall far short of the true ones - those motions in which the things that are really fast or really slow, as measured in true numbers and as forming all the true geometrical figures, are moved relative to one another, and that move the things that are in them. [...] It is probably that as the eyes fast on astronomical motions, so the ears fasten on harmonic ones, and that these two sciences are somehow akin, as the Pythagoreans say. And we agree, Glaucon, Don't we? (Republic 529d and 530a10)

Notice the same reference to astronomy and speed of motion, as well as the assertion that these sciences are akin. Notice also that numbers are the primary windows through which one attains knowledge of the visible world. It is also important that Plato refers to this text as "what the Pythagoreans say', since Archytas was a Pythagorean.

What is decidedly crucial, however, is that this conversation between Glaucon and Socrates occurs in Book VII of the Republic while they are discussing the model of Philosopher's education for the Philosopher Kings of Kallipolis. ${ }^{20}$ Recall also the idea from earlier that 'our guardian is both a warrior and a philosopher', which seems to fit the description of Archytas quite well. 
So, we know that Plato had met with Archytas on many occasions before he wrote the Republic. We also know that in the Republic the history of Tarentum's democratic institution is recapitulated almost verbatim when Plato describes how a political constitution might become democratic. We also see elements of Archytas' philosophy and ideas described verbatim in Book VII of the Republic, while Socrates and Glaucon are discussing the nature of education for the Philosopher Kings.

This is all circumstantial evidence, but it is highly suggestive. It is also important to take into account the difference between the city-states in Sicily, and Archytas's city-state in Taretum. We know Plato was not fond of the 'hedonism' he observed in Sicily, and later thought Dionysus II to be a tyrant. ${ }^{21}$ This is in stark contrast to Archytas, someone who was later admired by Aristotle and who was friends with Plato. We also know that Plato held this Pythagorean mathematician, philosopher, and guardian of Tarentum in higher esteem than at least one other city-state and its decidedly unphilosophical King (see Plato Seventh Letter, transl. by Huffman 2005). Once we realize these city-states were almost at constant war with one another, and that Plato thought war would cease when rulers became Philosopher Kings, the idea that Archytas was the inspiration for the Philosopher Kings of Kallipolis becomes much tighter.

\section{TOWARD CLASSICAL MICROHISTORY?}

I think Plato was extremely distraught after Socrates death, and traveled from city-to-city seeking wisdom, while the city-states were at constant war. During his sojourn he would have met Archytas and developed an interest in mathematics. He also probably got himself into serious trouble on a number of occasions, but was eventually reabsorbed back into the political order as a philosopher-elite. ${ }^{22}$

If this is correct then Plato's traumatic life experiences during a time of war, as well as the friendships he formed with philosophical/mathematical leaders like Archytas, would have inspired his essays in the Republic. Tarentum was then a really existing Pythagorean Kallipolis, replete with a mathematician Philosopher King, and served as domain of peace and wisdom for that ancient wandering sage named Plato.

Perhaps, this shows it is possible to do microhistorical investigations into this strange world-historical time period known as the Axial Age.

The Axial age was first coined by German Existentialist philosopher Karl Jaspers, who noticed that the Buddha, Pythagoras, and Confucius were all living around the same time period, and that India, Greece and China, all had similar political conditions. Warring States China, PreMauryan India, and Iron Age Greece were all collections of warring citystates, and they all produced what would later become dominant philosophical systems espoused by urban literati. 
Jaspers was not quite sure why such an outpouring of philosophical ideas and the development of imperial city-states all occurred simultaneously. But, perhaps by investigating key-thinkers, their trials and tribulations, and their eventual rise to key political positions, we can shed light onto this broader landscape of history.

I raise this issue at the end because while I have only focused on some narrow questions in this essay, the aim of microhistory is to shed light on very broad structures. And, Karl Jaspers, while writing a history of philosophical development, perhaps makes one of the grandest claims of all: that there is a pivot in human civilization in terms of philosophical development.

Could a collaborative effort of archaeologists, classicists, and microhistorians shed light on this interesting moment? Perhaps, it is best to end, although perhaps it is a bit cliché, with Jasper's claim.

If there is an axis in history, we must find it empirically in profane history, as a set of circumstances significant for all men, including Christians. It must carry conviction for Westerners, Asiatics, and all men, without the support of any particular content of faith, and thus provide all men with a common historical frame of reference. The spiritual process, which took place between 800 and $200 \mathrm{BC}$, seems to constitute such an axis. It was then that the man with whom we live today came into being. Let us designate this period as the 'axial age'. Extraordinary events are crowded into this period. In China lived Confucius and Lao Tse, all the trends in Chinese philosophy arose, it was the era of Mo Tse, Chuang Tse and countless others. In India it was the age of the Upanishads and of Buddha; as in China, all philosophical trends, including skepticism and materialism, sophistry and nihilism, were developed. In Iran Zarathustra put forward his challenging conception of the cosmic process as a struggle between good and evil; in Palestine prophets arose: Elijah, Isaiah, Jeremiah, Deutero-Isaiah; Greece produced Homer, the philosophers Parmenides, Heraclitus, Plato, the tragic poets, Thucydides, and Archimedes. All the vast development of which these names are a mere intimation took place in these few centuries, independently and almost simultaneously in China, India, and the West. The new element in this age is that man everywhere became aware of being as a whole, of himself and his limits. He experienced the horror of the world and his own helplessness. He raised radical questions, approached the abyss in his drive for liberation and redemption. And in consciously apprehending his limits he set himself the highest aims. He experienced the absolute in the depth of selfhood and in the clarity of transcendence. Conflict- 
ing possibilities were explored. Discussion, partisanship, intellectual schisms (though within a common frame of reference) gave rise to movement and unrest bordering on spiritual chaos. This era produced the basic categories in which we still think and created the world religions out of which men still live (Jaspers 1951: 37).

Is there a great pivot of human civilization? Could the Axial Age be something like the discovery of fire, the invention of agriculture, or the rise of urban development? And, finally, is microhistory a proper technique for the investigation of this question? One way to approach this concept might be similar to the methodology of this essay: try to look at the empirical conditions that gave rise to dominant books within the various philosophical canons. Plato's Republic is such a text. What concrete voices, lost philosophers, and dangerous experiences gave rise to such texts? How did such empirical conditions lead to the efflorescence of that extraordinary period called the Axial Age?

\section{NOTES}

1 'Although scale as an inherent characteristic of reality is certainly not an extraneous element in the microhistory debate it is, rather, tangential; for the real problem lies in the decision to reduce the scale of observation for experimental purposes' (Levi 1991: 6).

${ }^{2}$ This is a response to Robert Finlay (1988: 553-571). I guess it is easier for Finlay to imagine that Arnauld had the mysterious powers of wit peasant villagers attributed to him, than it is for Finlay to imagine an intelligent woman helped Arnauld out.

${ }^{3}$ To borrow from Willliam Blake.

${ }^{4}$ Others like the bailiff and the imperial-village-domus of the Carthar familypolitical-cosmological structure played a more direct role. I am simplifying this aspect of Ladurie's argument enormously. But, it is somewhat tangential to my claims.

${ }^{5} \mathrm{I}$ am indebted to friends in my graduate seminar for this connection.

6 'The last book devoted to Archytas was published over 160 years ago (Gruppe 1840). Even that work was not really a study of Archytas' thought but rather an unsuccessful attempt to argue that no authentic fragments of Archytas had survived from antiquity. It is not an exaggeration to say, then, that there has never been a book-length study of Archytas of Tarentum. There have not even been many shorter treatments. Erich Frank gave Archytas a fairly prominent role in his reconstruction of early Pythagoreanism (1923), but that reconstruction was eccentric and has been largely rejected by scholars. Essentially the only commentary has been that in Italian by Maria Timpanaro Cardini, as part of a threevolume commentary on all the Pythagoreans (1958-64). In recent years there have been a few important articles and sections of larger works dealing with isolated aspects of Archytas' work, notably his harmonic theory (e.g. Barker 1989, 1994; Bowen 1982; Cambiano 1998 and Lloyd 1990), but to say that Archytas has been 
neglected would be an understatement. Nonetheless, Archytas is one of the three most important figures in ancient Pythagoreanism (along with Pythagoras himself and Philolaus); we cannot hope to understand ancient Pythagoreanism without understanding Archytas. He was also an important philosopher, mathematician and political leader in his own right. Most scholarship on Greek philosophy during the first half of the fourth century has been devoted to Plato and the Academy. Archytas is a crucial figure for any attempt to understand Greek philosophy and mathematics outside of the Academy during this period and thus for understanding the broader environment in which both Plato and Aristotle developed as philosophers. It is astounding that Archytas, who represents the developed Pythagoreanism that 'makes a direct and personal impact on Plato himself' (Guthrie 1962: 333) and whom Gregory Vlastos has called a 'master metaphysician' and 'a new model philosopher for Plato' (1991: 129), has never been the subject of a complete study' (Huffman 2010 from preface).

${ }^{7}$ Plato might have been into slavery, and then ransomed by 'friends' the same year he founded the Academy, in 388/7 BC. In 399 BC his mentor Socrates died, and horrified, he turned to philosophy 'thinking it could put an end to civil war and political upheaval' Plato, Republic from the introduction by C.D.C. Reeve (p. ix).

${ }^{8}$ (Plb. X. 1) Fragment. (From here on F). See also (A4a).

${ }^{9}$ See Huffman 2010; Ingham 2004, and Dubois 2003. It is interesting that ancient colonizers did not develop a systematized anthropology, though clearly they developed almost every other subject.

${ }^{10}$ See Plato's Seventh letter.

${ }^{11}$ See Ingham 2004: 98-100 for his 'military-slavery-coinage' complex idea.

${ }^{12}$ Herodotus argues this was the greatest slaughter of Greeks he knew. He estimates 3,000 soldiers from Rhegium, Tarentine's ally, died, but places no number on the Tarentine deaths (Herodotus VII. 170).

${ }^{13}$ For archaeological evidence, Huffman recounts that 'Dedications at Delphi commemorated victories over the Messapians and Peucetians/Iapygians' Carl A. Huffman, Archytas of Tarentum, Pythagorean, Philosopher, and Mathematician King. See also (Paus. X. 10.6) and (Paus. X. 13.10). Translated with detailed discussion of philology and authenticity in Huffman.

${ }^{14}$ Thucydides notes that Athens had a total of 29,000 footsoldiers and 3,000 Calvary at the start of the Peloponnesian War (Gomme 1956, Hornblower 1994).

15 'The first strand is represented by texts A5b1-b13. There is considerable variation from passage to passage but two elements are crucial: (1) Upon the Death of Socrates in 399, Plato, at age 27 cast about looking for new teachers and new sources of wisdom. (2) One of the places where Plato sought instruction was the Pythagorean school in southern Italy and Sicily, and Archytas is regularly listed as one of the Pythagoreans whom Plato sought out. [...] The second strand is represented by texts $\mathrm{A} 5 \mathrm{c} 1$ to $\mathrm{A} 5 \mathrm{c} 3 \ldots$ The central features of this strand are: (1) Archytas is presented as primarily a political figure who only achieves power after and because of studying with the philosopher Plato. (2) Archytas and Plato are just one of a series of statesmen philosopher pairs' (Huffman 2010: 34). 
16 'The evidence seems fairly solid that Plato did indeed make a trip to southern Italy not too long after the death of Socrates' (Huffman 2010: 40).

${ }^{17}$ This is exactly Huffman's hypothesis in fact.

${ }^{18}$ Philolaus's writings are becoming a foundation for the study of Pythagoreanism.

${ }^{19}$ Whereas for Plato the goal is knowledge of the invisible world. See Republic, Book VII. While it seems as though Archytas agrees much of the world is invisible to us, being unable to pour into our senses, he is only concerned with trying to understand what we can observe.

${ }^{20}$ Book VII also has the famous Allegory of the Cave.

${ }^{21}$ There is a long discussion of this in Plato's Seventh Letter. The Seventh letter has a number of authenticity problems with it and these are discussed in detail Huffman 2005. I am following his suggestion that many of the views expressed concerning hedonism and Sicily, however, are accurate. Also C. D. C. Reeve accepts the authenticity of the letter in his newest edition of the Republic (Reeve 2004).

${ }^{22}$ Probably the most colorful story is in Tstvetez, which has Plato being put on the auction block in Aegina, only to be ransomed by a philosopher of the Epicurean school, Annikeris. Later, he was saved by 'guest friends,' perhaps Archytas. In this version, Plato's friends raise money to pay Annikeris back, but Annikeris refuses to accept the money, saying it was his honor to save a fellow lover of wisdom. Plato then uses the money to found his famous Academy (for translation of this fragment see Huffman 2005).

\section{REFERENCES}

Barker, A. D. 1989. Greek Musical Writings. Vol. II: Harmonic and Acoustic Theory. Cambridge: Cambridge University Press.

Barker, A. D. 1994. Ptolemy's Pythagoreans, Archytas, and Plato's Conception of Mathematics. Phronesis 39 (2): 113-135.

Bowen, A. C. 1982. The Foundations of Early Pythagorean Harmonic Science: Archytas, Fragment 1. Ancient Philosophy 2: 79-104.

Cambiano, G. 1998 [1996]. Archimede Meccanico et La Meccanica di Archita. Elenchos 19 (2): 291-324.

Davis, N. Z. 1983. The Return of Martin Guerre. Cambridge, MA: Harvard University Press.

Davis, N. Z. 1988. On the Lame. The American Historical Review 93 (3): 572-603.

Dubois, P. 2003. Slaves and Other Objects. London: University of Chicago Press.

Finley, M. I. 1985. Ancient Economy. Berkley: University of California Press.

Finlay, R. 1988. The Refashioning of Martin Guerre. American Historical Review 93 (3): 553-571.

Frank, E. 1923. Plato und die sogenannten Pythagoreer: Ein Kapitel aus der Geschichte des griechischen Geistes. Halle. 
Ginzburg, C. 1980. The Cheese and the Worms. Baltimore: Johns Hopkins University Press.

Gomme, A. W. 1956. A Historical Commentary on Thucydides. Vol. II. Oxford University Press.

Gruppe, O. F. 1840. Über die Fragmente des Archytas und der ältern Pythagoreer. Berlin.

Guthrie, W. K. C. 1962. A History of Greek Philosophy. Vol. I. Cambridge: Cambridge University Press.

Huffman, C. A. 2006. Philolaus of Croton. Pythagorean and Presocratic. New York: Cambridge University Press.

Huffman, C. A. 2010. Archytas of Tarentum: Pythagorean, Philosopher and Mathematician King. New York: Cambridge.

Hornblower, S. 1994. A Commentary on Thucydides. Vol. 1. Oxford University Press.

Ingham, G. 2004. The Nature of Money. Cambridge: Polity Press.

Jaspers, K. 1951. The Way to Wisdom. Transl. by. R. Manheim. New Haven: Yale University Press.

Le Roy Ladurie, E. 1978. Montaillou. London: Scolar Press.

Levi, G. 1991. On Microhistory. In Burke, P. (ed.), New Perspectives on Historical Writing (pp. 93-113). Cambridge: Polity Press.

Lloyd, G. E. R. 1990. Plato and Archytas in the Seventh Letter. Phronesis 35 (2): 159-174.

Reeve, C. D. C. 1988. Aristotle. Politics. Transl. by G. M. A. Grube, revised by C. D. C. Reeve. Indianapolis, IN: Hackett Publishing Company.

Reeve, C. D. C. 2004. Plato. Republic. Transl. from the new standard Greek text, with Introduction by C. D. C. Reeve. Indianapolis, IN: Hackett Publishing Company.

Sturgis, R., and Davis, F. A. 2013. Sturgis' Illustrated Dictionary of Architecture and Building: An Unabridged Reprint of the 1901-1902 Edition. Dover Publications.

Vlastos, G. 1970. Equality and Justice in Early Greek Cosmologies. In Furley, D. J., and Allen, R. E. (eds.), Studies in Presocratic Philosophy. Vol. 1 (pp. 56-91). London: New York.

Wright, D. R. 2010. The World and Very Small Place in Africa. New York: M. E. Sharpe. 


\section{Appendix}

\section{Original Fragments}

(For original Doric see Huffman 2010)

\section{Fragment 1}

A. Porphyry, On Ptolemy's Harmonics 1. 3 (Düring 55.27-58.4)

But now in addition let the words of Archytas the Pythagorean, whose writings most of all are said to be indeed genuine, be cited. In On Mathematics, just as he begins the discourse, he says the following:

Those concerned with the sciences seem to me to make distinctions well, and it is not at all surprising that they have correct understanding about individual things as they are. For, having made good distinctions concerning the nature of wholes they were likely also to see well how things are in their parts. Indeed concerning the speed of the stars and their risings and settings as well as concerning geometry and numbers and not least concerning music, they handed down to us a clear set of distinctions. For these sciences seem to be akin. Well then, first they reflected that it is not possible that there be sound, if an impact of some things against one another does not occur; they said that an impact occurred whenever things in motion came upon and collided with one another. Some moving in opposing directions, when they meet, make a sound as each slows the other down, but others moving in the same direction but not with equal speed, being overtaken by the ones rushing upon them and being struck, make a sound. Indeed many of these sounds cannot be recognized because of our nature, some because of the weakness of the blow, others because of the distance of separation from us and some because of the excess of the magnitude. For the great sounds do not steal into our hearing, just as nothing is poured into narrow-mouthed vessels, whenever someone pours out a lot. Well then, of the sounds reaching our perception those which arrive quickly and strongly from impacts appear high in pitch, but those which arise slowly and weakly seem to be low in pitch. For if someone should pick up a stick and move it sluggishly and weakly, he will make a low sound with his blow, but if quickly and strongly, high. Not only by this would we recognize the fact, but also whenever either speaking or singing we wish to voice something loud and high, since we speak with a violent breath. But further this also happens, just as with missiles. Those which are hurled strongly are carried far, those weakly, near. For to those moving vigorously the air yields more and to those moving weakly less. The same thing will also happen with vocal sounds.

The one carried by a strong breath will turn out to be loud and high, the one by a weak one, soft and low. But indeed we can also see this fact from this strongest sign, that we can hear the same man speaking loudly from far off but speaking softly not even from near at hand. But indeed also in flutes, the breath moving from the mouth and falling into the openings near the mouth produces a higher sound because of the great force, but that falling into the holes further away, produces a lower sound. So that it is clear that quick motion makes a high sound and slow motion a low sound. But indeed the same thing also happens to the rhomboi, which are whirled in the mysteries. If they are moved calmly, they produce a low sound but, if forcefully, a high sound. But also indeed, a reed, if someone, having blocked the lower part of it, blows in it, he will, you know, produce a low sound. 
But if he blows into the half or whatever part of it, it will sound high. For the same breath is carried weakly through a long distance and strongly through a shorter distance.

Having said other things about the motion of voice being according tointervals he summarizes the argument thus:

It has become clear to us from many things that high notes move more quickly and low ones more slowly. Fast motion makes a high sound and slow motion a low sound. But indeed the same thing also happens to the rhomboi, which are whirled in the mysteries. If they are moved calmly, they produce a low sound but, if forcefully, a high sound. But also indeed, a reed, if someone, having blocked the lower part of it, blows in it,he will, you know, produce a low sound. But if he blows into the half or whatever part of it, it will sound high. For the same breath is carried weakly through a long distance and strongly through a shorter distance.

B. Porphyry, On Ptolemy's Harmonics (Düring 80.28-81.16; for the apparatus and the text of the quotation from Archytas see Text A above)

Such are the words of Aristoxenus. If, however, as the Pythagoreans say, the harmony of the whole universe exceeds our hearing on account of the magnitude of the sounds, the limit of sounds would be greater than the limits of hearing. For the harmony of the whole would comprise both the highest and lowest sounds, with regard to which our hearing fails.

Archytas, whose text we also cited before, writes the following things about sounds:

Indeed many of these sounds cannot be recognized because of our nature, some because of the weakness of the blow, others because of the distance of separation from us and some because of the excess of the magnitude. For the great sounds do not steal into our hearing, just as nothing is poured into narrow-mouthed vessels, whenever someone pours a lot. But let these things be enough on this topic. It is clear from these things that this intelligible ordering of melody, in itself, would seem to increase without limit, but, if it is transferred to the voice and the hearing, it does not have an unlimited extension but is limited by our ability.

C. Nicomachus, Introduction to Arithmetic 1. 3.3 (p. 6.8-7.6 Hoche; for the apparatus see Text $A$ above)

Without these [arithmetic, music, geometry, sphaeric], then, it is not possible to be exact about the forms of being nor to discover the truth in the things that are, the knowledge of which is wisdom, and, it appears, not even to philosophize correctly. For just as painting contributes to handicrafts with regard to correctness of theory, so lines and numbers and harmonic intervals and revolutions of circles provide a contribution towards learning wise discourses, says Androcydes the Pythagorean. But Archytas of Tarentum as he begins his Harmonics also says the same thing, in about these words: Those concerned with the sciences seem to me to make distinctions well, and it is not at all surprising that they have correct understanding about individual things as they are. For, having made good distinctions concerning the nature of wholes they were likely also to see well how things are in their parts. Indeed concerning geometry and arithmetic and sphaeric they handed down to us a clear set of distinctions and not least also concerning music. For these sciences seem to be akin. This is so, because they are concerned with the two primary forms of being which are akin. 
Text D. Iamblichus, On Nicomachus' Introduction to Arithmetic 118.19119.3 (Pistelli)

We must now speak about the most perfect proportion, which consists of four terms and is properly called musical, because the musical ratios of the concords in harmony are most clearly embraced in it. They say that it is a discovery of the Babylonians and that it came into Greece through Pythagoras first. At any rate, many of the Pythagoreans are found using it, such as Aristaeus of Croton and Timaeus of Locri, and the Tarentines Philolaus and Archytas, and many others, and afterwards Plato in the Timaeus, speaking as follows...

Fragment 3 (trans. Huffman 2010: 183)

Iamblichus, On General Mathematical Science 11 (44.10-17 Festa)

Wherefore Archytas says in the On Things Scientific: For it is necessary to come to know those things which you did not know, either by learning from another or by discovering yourself. Learning is from another and belongs to another, while discovery is through oneself and belongs to oneself. Discovery, while not seeking, is difficult and infrequent but, while seeking, easy and frequent, but, if one does not know how to calculate, it is impossible to seek. Once calculation was discovered, it stopped discord and increased concord. For people do not want more than their share, and equality exists, once this has come into being. For by means of calculation we will seek reconciliation in our dealings with others. Through this, then, the poor receive from the powerful, and the wealthy give to the needy, both in the confidence that they will have what is fair on account of this. It serves as a standard and a hindrance to the unjust. It stops those who know how to calculate, before they commit injustice, persuading them that they will not be able to go undetected, whenever they appeal to it as a standard. It hinders those who do not know how to calculate from committing injustice, having revealed them as unjust by means of it [i.e. calculation].

A1 Diogenes Laertius, Lives of the Philosophers VIII. 79-83 (Huffman 2010: 256).

Archytas of Tarentum, the son of Mnesagoras or, according to Aristoxenus, of Hestiaios, was also himself a Pythagorean. He is the one who rescued Plato by means of a letter, when he was about to be killed by Dionysius. He was also admired among the multitude for every virtue. Indeed, he served as general (strat ${ }^{-}$egos) of his fellow citizens seven times, although others served no more than a year because the law prevented it. Plato has also written two letters to him, since Archytas had written to him first in the following fashion. (There follows a spurious letter of Archytas to Plato and Plato's response. See Thesleff 46.1-7 and Plato, Ep. xii).

A1f Synesius, On the Gift of the Astrolabe II. 5 ff. (308c, Terzaghi 1944: 134, 7-16) (Huffman 2010: 260).

Archytas of Tarentum, son of Hestiaios or Mnesarchos or Mnasagetes or Mnasagoras, a Pythagorean philosopher. He saved Plato from being murdered by Dionysius the tyrant. He was the leader of the Italian league and was chosen general with special powers by the citizens and the Greeks in that region. At the same time also, as a teacher of philosophy, he both had students of high reputation and also wrote many books. [They say] that he was manifestly the teacher of Empedocles. And there is the proverb, 'a clapper of Archytas', because Archytas 
invented a clapper, which is a kind of instrument that produces a resounding noise. And he having forged a clapper from bronze was making it clap. (This last sentence is probably a reference to Heracles, who used a clapper to scare away the birds from the Stymphalian Lake. See A. R. ii. 1055).

A4 Strabo, Geography VI. 3.4 (C. 280) (Huffman 2010: 265)

The Tarentines were once exceedingly powerful, when they had a democratic government. For they possessed the greatest fleet of those in the region and sent to battle 30,000 footsoldiers, 3,000 cavalry, and 1,000 mounted javelin throwers. They also adopted the Pythagorean philosophy, especially Archytas, who was also the leader of the city for a long time. The luxury, which developed later because of their prosperity, prevailed to such an extent that more city-wide festivals were conducted by them each year than there were days in the year.

A4a L. Annaeus Florus, Epitome of Roman History I. 13.2-3

Tarentum, foundation of the Lacedaemonians, once the capital of Calabria, Apulia and all of Lucania, is both famous for its size, walls and port and also remarkable for its situation. Indeed, situated at the very entrance to the Adriatic sea, it sends forth ships into all lands, to Istria, Illyricum, Epirus, Achaea, Africa and Sicily.

A5b13 Tzetzes, Histories X. 988-92 (Leone 1968: 429) (Huffman 2010: 274).

Archytas bought the philosopher Plato from the admiral Polis, a Spartan.

Archytas was also a philosopher but from the Pythagorean school. After he acquired Plato as a slave, he also taught the Pythagorean philosophy to him.

Text F. Valerius Maximus, Memorable Deeds and Sayings IV. 1. ext. 1 ( $1^{\text {st }}$ century A.D.) (Huffman 2010: 286).

Archytas of Tarentum immersed himself completely in the teachings of Pythagoras at Metapontum and with great and long labor embraced the complete course of training. After he returned to his fatherland and began to review his estates, he became aware that they had gone to wrack and ruin by the negligence of his steward. Looking at the culprit he said, 'I would have punished you, if I were not angry with you'. For he preferred to let him go unpunished rather than, because of his anger, to punish him more severely than was just. The moderation of Archytas was too generous, that of Plato more temperate. For, when he had become too violently angry in response to the offense of a slave, fearing lest he himself not be able to discern the proper amount of punishment, he entrusted the determination of the punishment to his friend Speusippus... 